\title{
Entrepreneurial Career Choice: A Study among MBA Students from Universiti Teknologi Malaysia
}

\section{Shathees Baskaran, Nomahaza Mahadi and Siti Zaleha Abdul Rasid}

To Link this Article: http://dx.doi.org/10.6007/IJARBSS/v10-i11/8255 DOI:10.6007/IJARBSS/v10-i11/8255

Received: 09 September 2020, Revised: 20 October 2020, Accepted: 18 November 2020

Published Online: 30 November 2020

In-Text Citation: (Baskaran et al., 2020)

To Cite this Article: Baskaran, S., Mahadi, N., \& Rasid, S. Z. A. (2020). Entrepreneurial Career Choice: A Study among MBA Students from Universiti Teknologi Malaysia. International Journal of Academic Research in Business and Social Sciencess, 10(11), 1318-1333.

\section{Copyright: (C) 2020 The Author(s)}

Published by Human Resource Management Academic Research Society (www.hrmars.com)

This article is published under the Creative Commons Attribution (CC BY 4.0) license. Anyone may reproduce, distribute, translate and create derivative works of this article (for both commercial and non-commercial purposes), subject to full attribution to the original publication and authors. The full terms of this license may be seen at: http://creativecommons.org/licences/by/4.0/legalcode

Vol. 10, No. 11, 2020, Pg. 1318 - 1333

Full Terms \& Conditions of access and use can be found at http://hrmars.com/index.php/pages/detail/publication-ethics 


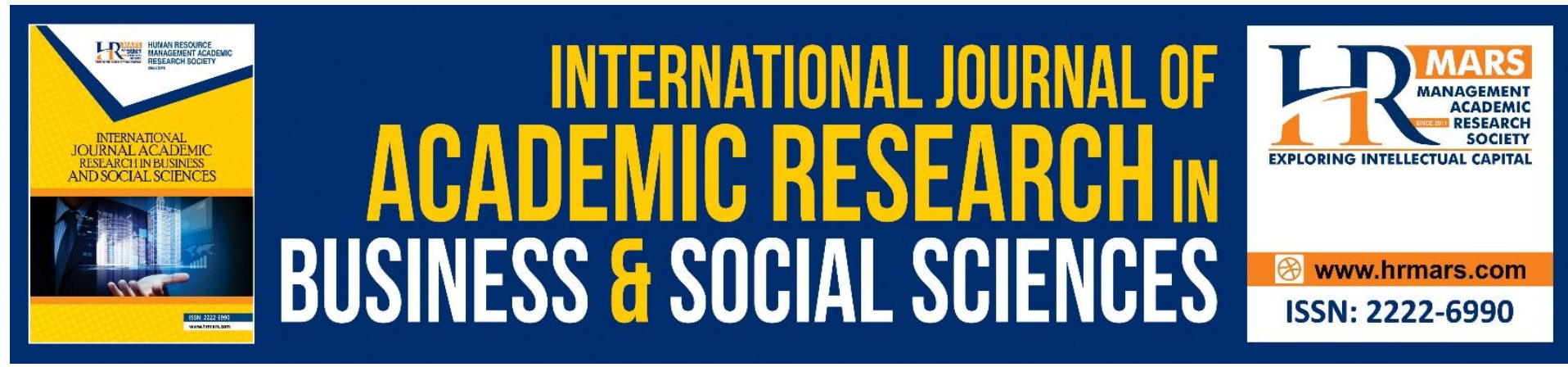

\title{
Entrepreneurial Career Choice: A Study among MBA Students from Universiti Teknologi Malaysia
}

\section{Shathees Baskaran, Nomahaza Mahadi and Siti Zaleha Abdul Rasid}

International Business School, Level 10, Menara Razak, Universiti Teknologi Malaysia, Jalan Sultan Yahya Petra, 54100 Kuala Lumpur.

Email: shathees@utm.my

\begin{abstract}
The economic slowdown and limited employment opportunities are opening the path for more self-employment opportunities. This allows unemployed students or students with an entrepreneurial mindset to utilize the knowledge and also skills learned through an MBA program and put them into practice in their entrepreneurial endeavors. As a result, some higher learning institutions have started their entrepreneurship programs or courses to equip the students with the knowledge and also skills for their self-employment upon graduation. Therefore, this study attempts to investigate the influence of entrepreneurship education and entrepreneurial career choice among MBA students. Employing quantitative research, 238 MBA students of UTM participated in this survey. The results indicated that there is a significant positive relationship between entrepreneurship education and entrepreneurial career choice. Additionally, instrumental readiness was found to mediate this relationship.
\end{abstract}

Keywords: Entrepreneurial Career Choice, Entrepreneurial Education, Instrumental

Readiness

\section{Introduction}

Continuous hits to the global economy have become unavoidable due to uncertain external forces. This has made many countries to suffer economic health. In spite of these challenges, Nafukho and Helen Muyia (2010) proved that entrepreneurship is vital in creating and fulfilling a healthy economy. This is supported by Dickson, Solomon and Mark Weaver (2008) where the growth of entrepreneurship is significant to a country's economy. Hence, selfemployment is seen as a gateway to the labor markets. This is true especially to university graduates who suffer a lack of experience demanded by the organizations. Setiawan (2012) argued that the university needs to prepare students to face the challenges in their life after completing their studies. A successful entrepreneurial education curriculum leads many university graduates to venture into new business creations as a path to entering the labor market. However, self-employment requires the necessary skills to be successful given a dynamic business environment. 


\section{Problem Statement}

It is a common phenomenon that people move between paid employment and entrepreneurship including its culmination in a transition to entrepreneurship however, it has gained scholar's attention recently only (Burton, Sorenson \& Dobrev, 2016). Several authors (e.g. Beckman \& Burton, 2008) claimed that people tend to be entrepreneurs after serving an established for several years. Nevertheless, according to Mohammad Ismail et al (2009), there is a high possibility that youngsters who take up entrepreneurial subjects will have a strong inspiration to become entrepreneurs. This is in contradictory to Burton, Sorenson, and Dobrev (2016) who indicated some research demonstrates that there is no relationship between educational attainment since it can be driven by necessity (e.g. Joona \& Wadensjo, 2013) or opportunity (e.g. Sorensen \& Sharkey, 2014; Joona \& Wadensjo, 2013; Lofstrom, Bates, \& Parker, 2014; Carnahan, Agarwal, \& Campbell, 2012). In view of rapid changes in environment, many universities have started to offer entrepreneurship or entrepreneurshiprelated courses in their curriculum (Adejimola \& Olufunmilayo, 2009) with an objective which ranges from creating awareness, strengthening entrepreneurial capacity, instill risk-taking behavior, embracing change to develop the entrepreneurial skills and entrepreneurial attitude (Ahmadpur Dariani, 2004). The intention of the entrepreneurial education curriculum is to develop entrepreneurial skills among university graduates that will generate employment and income (Dutta \& Crossan, 2005). According to Zabihi and Moghaddassi (2006), entrepreneurship education curriculum enables knowledge and information transfer that is needed in setting up and running a new venture with a hope that such endeavors will reduce unemployment and enhances business success (Yurbano, 2008). Therefore, the entrepreneurship education curriculum has become instrumental in instilling entrepreneurial characteristics in higher education design. Several researchers (e.g. Dopson \& Tas, 2004; Gursoy \& Swanger, 2004; 2005) claimed that an entrepreneurially oriented curriculum provides substantial knowledge, drive, values and skills to run a business. Lunenburg and Ornstein (2004) further iterated this notion saying that curriculum remains the core and heart of the academic system which determines the orientation and directions of activities and assessments to be carried out. This is because a curriculum depicts a series of educational events, which will be then assessed in measuring the expected learning outcomes (Elliot Eisner, 1994) which involve internalization of the concepts, attitudes and skills. Although entrepreneurship education curriculum found to reduce unemployment, Maleki (2008) posited that there is no consensus about this field over the concept of the curriculum. Aside, less attention has been paid in understanding entrepreneurial curriculum, objectives, content, and teaching methods of entrepreneurship (Ahmadzadeh, 2006).

\section{Research Objectives}

Therefore, the purposes of this study are to investigate (1) the relationship between entrepreneurial education curriculum and entrepreneurial career choice and (2) the mediating effect of instrumental readiness between entrepreneurial education curriculum and entrepreneurial career choice among UTM MBA students. The theoretical benefit of this research is to add to the existing body of knowledge in the field of entrepreneurship. This research is expected to provide a picture of the entrepreneurship education curriculum and its ability to foster entrepreneurial career as a choice of employment among MBA students in UTM. More specifically, this research aims to achieve the following objectives: 
a. Determine the relationship between Entrepreneurship Education Curriculum and Entrepreneurial Career Choice.

b. Determine the mediating effect of Instrumental Readiness on the relationship between Entrepreneurship Education Curriculum and Entrepreneurial Career Choice.

\section{Literature Review}

\section{Entrepreneurial Career Choice}

Sidek (2006) explained that career remains an essential element for everyone as it shapes life. The decision making of a career choice is also equally complex and time-consuming (Olsson \& Frey 2002). In spite of the traditional belief that professional achievement is a factor of success (Wiese, Freund, \& Baltes, 2002), Baruch (2006) argued that the organizational systems are very dynamic today and does not provide assurance of employability. The career journey has gone boundaryless (Ashkenas, Ulrich, Jick, \& Kerr, 1995) and has been always subject to uncertainty, complexity, and flexibility (Baruch, 2006). There is a change in norms, values, and attitudes in life (Polach, 2004) and the means of success have been redefined (Gunz \& Heslin, 2005). Several researches were conducted among university graduates to understand their adoption of an entrepreneurial career as their employment choice. Among others, it includes work values, career intentions and attitudes (Brenner, Pringle, \& Greenhaus, 1991, Krueger, 1993), and entrepreneurial career aspirations (Scott \& Twomey, 1988). Although entrepreneurship can be a choice for many, it may not be suitable for everyone. However, the decision to pursue an entrepreneurial career may be regarded as the closest prerequisite for a successful entrepreneurial career (Schmitt-Rodermund, 2004). Adoption of an entrepreneurial career requires that the incumbent considers various factors before making a definitive choice. One of the main factors which are of consideration to graduates adopting an entrepreneurial career is education-related factors (Von Broembsen et al., 2005; Kroon \& Meyer, 2001). The education factor involves modules and teaching approaches in entrepreneurship that may affect students' attitudes and intentions towards entrepreneurship (Nieuwenhuizen \& Groenewald, 2008; Kroon \& Meyer, 2001). For instance, studies provided evidence that participation in entrepreneurship courses increases the tendency of new venture creation in comparison to the others (Owusu-Ansah \& Fleming, 2001; Ibrahim \& Soufani, 2002). Nevertheless, several scholars (e.g. Dyer, 1994) indicated that the career literature has scarcely addressed self-employment or entrepreneurship as a distinct career option although according to Din (2002), there is an increasing trend of entrepreneurship career due to the opportunities it offers. This is why entrepreneurship as a career choice has represented one of the most debated subjects in the literature since the early 2000s (Segal et al., 2005; Douglas \& Shepherd, 2002; Henderson \& Robertson, 2000).

\section{Entrepreneurship Education Curriculum}

According to Chambers (2005), turning a university from a traditional education provider to an entrepreneurial university requires a well-designed entrepreneurial curriculum in the university offerings. Among others, the curriculum shall include areas such as resource and finance management, marketing and sales skills, innovation and exploring opportunities, business planning, firm management, organizing, and team-building, creating new businesses, small business management, and risk-taking (Mwasalwiba, 2008). Aside, changes are also required in structural, administrative, and cultural dimensions within the institutions (Fakour, 2008). In line with that, higher learning institutions in Malaysia have started to 
include entrepreneurship education curriculum as one of the main areas in the 1990s. Research conducted in the Malaysian context revealed that formal education may produce entrepreneurs (Yu \& Chan, 2007). This claim was further complemented by several researchers (Henderson \& Robertson, 2000; Kolvereid \& Moen, 1997) who argue that grooming a student towards entrepreneurship requires entrepreneurial education and knowledge. However, research evidence provided by Plattner (2009) indicated that very few graduates are psychologically ready and interested in pursuing self-employment as a future career choice. An important insight of this research was that the graduates had a fear of failing to associate themselves with the right networks and failing to obtain the right opportunity as a reason for not adopting self-employment as a career choice. Therefore, Setiawan (2014) acclaimed that it is important for entrepreneurial education to develop mental and psychological assets so that the self-employment adopters are more confident in making such a career choice. However, incorporation of these assets requires the entrepreneurial education curriculum to adopt different merits (Norouzzadeh \& Kowsari, 2009) and various methods such as exploratory learning, statement of problems, cooperative learning, simulations, and role-playing (Yadollahi, 2009; Martin \& Romita, 2014) so that the output of the entrepreneurial education curriculum will be more market- and business-oriented than knowledge-oriented (Ahmadpur Dariani \& Azizi, 2003). In support of this claim, four fundamental components of the entrepreneurship education curriculum were identified by Imani (2009) which include philosophy and objectives, theoretical fundamentals, elements of entrepreneurial programs, and environmental factors. These requirements were proven to be important by research conducted by Sharif et al (2011), Owladiyan (2010) and Jafari Moghadam (2012) whereby the findings collectively indicated that educational objectives, content, teaching and learning process and strategies, management, monitoring, risk-taking, creativity, and educational assessment practices are prominent areas of an entrepreneurship education curriculum. However, Gibb (2002) further simplified these findings into three main categories namely developing a wide understanding of entrepreneurship, acquisition of entrepreneurial mindset, and knowledge on how to start an enterprise effectively. According to Katz (2003), the entrepreneurship education curriculum is best placed to equip students with the necessary knowledge and skills required for entrepreneurial career choice. Contradictory to this claim, Anderson and Jack (2008) argued that entrepreneurship education is a difficult area to lecture due to its variability, complexity and contingency. In addition to this claim, Matlay (2008) indicated that there is no harmony between graduates' needs for entrepreneurship education and real outcomes in terms of entrepreneurial skills, knowledge and attitudes. This mismatch could be attributed to a corollary of inadequate or insufficient incorporation of the entrepreneurial education curriculum in the learning process. However, as a way forward in further understanding the debates on entrepreneurial education curriculum, Kuratko (2014) clarified the issue by offering a clarity that entrepreneurial education curriculum should not aspire to answer 'can entrepreneurship be taught", instead it should attempt to investigate "what should be taught and how should it be taught?"

\section{Instrumental Readiness}

Indarti and Rostiani (2008) explain that the instrumental readiness concept in entrepreneurship literature considers the impacts of three main areas: access to capital, availability of information and quality of social networks. Additionally, Ali, Topping, and Tariq (2011) further explained that instrumental readiness involves support from family and friends 
as well which Turker and Selçuk (2009) defined as relational support. Capital is the foundation of any new business. It refers to the financing option an entrepreneur may choose in the new venture. However, the availability of capital remains a challenge in developing countries as the capital resource is not too easily available or flexibly accessible (Indarti \& Rostiani, 2008) in comparison to developed countries. While access to capital has been the major setback in most entrepreneurial ventures (Steel, 1994), Mat, Maat, and Mohd (2015) clarified that when an entrepreneur faces challenges with access to capital, own savings and also financial support from family and friends becomes an option in new ventures. According to Singh and Krishna (1994), the intention to access information in entrepreneurial endeavors is important for all entrepreneurs. An entrepreneur should not discount the crucial importance of the information and the availability and access to this information is sometimes very challenging (Indarti \& Rostiani, 2008). The information enables the development and growth of new ventures. The information could be in the form of opportunity identification, sourcing for financing information, the information in view of the market and its developments and also other information which is pertinent to the new venture needs to set up and run the business. Aside, a strong social network is also important to an entrepreneur. According to Azahari et al. (2013), a social network is a business tool that plays a significant role in the success of the entrepreneurs which facilitates the attainment of tangible and intangible resources from the social networks. Involvement in social networking is found to enable growth and survival of business ventures (Huggins, 2000) through direct and indirect infiltration of both tangible and intangible resources (Mat, Maat \& Mohd, 2015). Aside, a quality social network is also expected to facilitate the exchange of information as well as business ideas or other business crucial information during the networking process (Indarti \& Rostiani, 2008). As mentioned by Singh and Krishna (1994), frequency and quality social network may enable the collection of credible information which will facilitate entrepreneurial ventures and this is said to be also influenced by personal characteristics of constituents involved in the interaction (Kristiansen, Furuholt and Wahid, 2003).

\section{Conceptual Framework}

Hence, based on this discussion, the following hypotheses were formulated:

$\mathrm{H1}$ : There is a significant relationship between entrepreneurship education curriculum and entrepreneurial career choice.

$\mathrm{H} 2$ : There is a mediating effect of instrumental readiness between entrepreneurship education curriculum and entrepreneurial career choice.

Based on these testable hypotheses, the theoretical framework of the study is shown in figure 1 below.

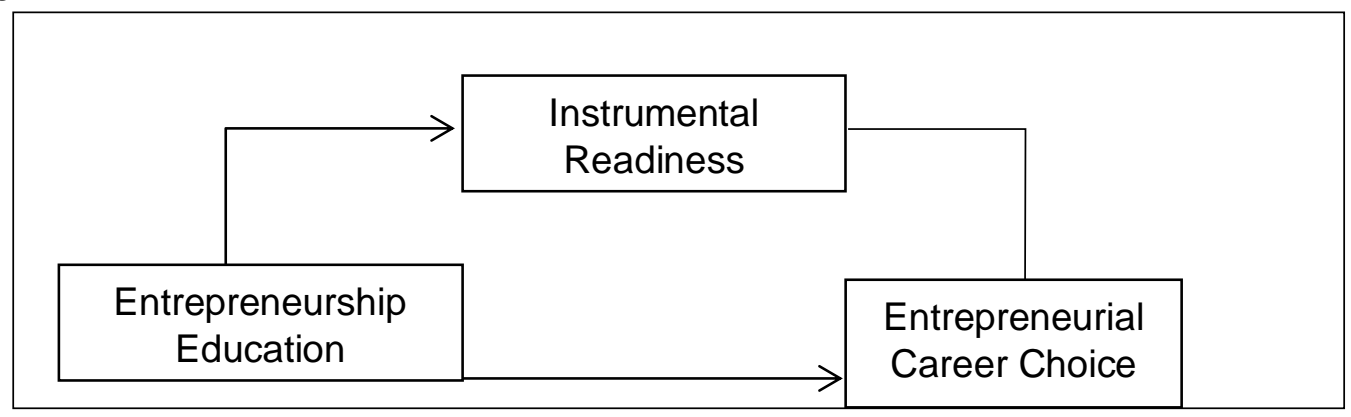

Figure 1: Conceptual Framework 


\section{Research Methodology \\ Research Design}

There are two legitimate ways to investigate an issue which are quantitative and qualitative research that differs in its degree of the researcher's immersion within the context being analyzed (Johnson \& Christensen, 2012). Current research studies are becoming increasingly diverse and inclusive of both qualitative and quantitative methods (Guest, Namey \& Mitchell, 2013). The research was carried out by conducting quantitative research by employing a questionnaire. The questionnaire-based survey is employed because it has acceptability within the fields of social and management sciences for collecting measurable data from a target population (Fanning, 2005). Quantitative survey method found to be more accurate and reliable (Clark, 1998) in quantifying the relationship between variables (Khalid, Hillman \& Kumar, 2012) as the numbers impress better (Snider, 2010). As suggested by lacobucci and Churchill (2015), the basis of this research will be causal research as it is deemed to be one of the best ways to determine the relationship between variables under study. Causal research which utilizes quantitative data to generate statistics about variables under study makes inferences apart from eliciting evidence of these relationships (Malhotra, 2002). This method is expected to produce more accurate and reliable insights in understanding the phenomenon under investigation.

\section{Measures and Instrumentation}

While the nominal measurement was used to obtain general information, a 5-point Likert scale was used to collect responses about the test instruments under study. This is because most studies settled at a minimum of 4 - 5 scales and five-points-Likert-scale is one of the common continuums for the respondents to locate their attitudes (Wolfer, 2007). The fivepoints-Likert-scale will range over 'strongly disagree", "disagree", "neutral", "agree" and "strongly agree" where the scoring will range from 1 to 5 respectively.

As far as instruments concerned, previously developed instruments were adopted and some minor modifications were done to make it applicable to the context of the study. Test instrument for entrepreneurship education curriculum was adapted from previous work by Roomi and Harrison (2011) who adapted their instruments from the Entrepreneurial Leadership Questionnaire by Eggers and Leahy (1992). This test instrument consists of eight items. Test instrument and items for entrepreneurial career choice was adapted from Linan and Chen (2009). This instrument measured by five test items while instrument developed by Kristiansen and Indarti (2004) was used to measure instrumental readiness encompassing access to capital, network, and information. This variable was tested with three items.

\section{Population, Sample, and Sampling}

The target population of the study was MBA students of Universiti Teknologi Malaysia from its campuses in Kuala Lumpur, Johor Bahru, Negeri Sembilan and also Sarawak. A total of 378 students made up the population of this research. This research occupied a convenience sampling method considering that the sampling units were chosen conveniently from a population for the distribution of questionnaires (Coldwell \& Herbst, 2004). Convenient sampling is usually selected considering proximity, availability, accessibility of research respondents (Saunders, Lewis, \& Thornhill, 2012). Since the contacts of the respondents are readily available, hence, convenient sampling was found to be more appropriate for this research. 


\section{Data Collection Procedures}

A structured questionnaire was developed and distributed to collect the required data. Survey which allows a researcher to collect sizeable amount of data in an economical way (Saunders, et al., 2012) is one of the popular and common data collection method in business and management studies (Saunders, et al., 2006) that is easy to administer because people are familiar with survey mechanism (Fraenkel \& Wallen, 2006). This is because the use of an internet-based web survey is highly accepted and more popular (Dillman, 2007) and therefore, this approach expected to reach a maximum number of respondents. An online web survey using a self-administered questionnaire will be used to collect the data because web-based surveys are inexpensive (Sheehan \& Hoy, 1999) and becoming increasingly common among respondents (Lazar \& Preece, 1999). In order to avoid missing data, all questions were made mandatory as such all responses received were made usable for the analysis. Overall, the online survey consisted of 21 questions for four main areas: i. demographic information (five items); ii. Entrepreneurship education (eight items); iii. entrepreneurial career choice (five items) and iv. instrumental readiness (three items). A follow up was made to improve the response rate from the respondents to ensure the generalizability of the research findings (Rea \& Parker, 2005).

\section{Reliability}

Tavakol and Dennick (2011) indicated that a reliable and valid test instrument is important in empirical studies. While reliability determines the consistency and repeatability of the results in different circumstances but within an identical situation (Twycross and Shields, 2004), validity ensures that the test instrument employed in a research measures what the test instruments intend to measure (Thatcher, 2010). In view of this, a pilot study was conducted among 15 respondents and the results are reported in Table 1:

Table 1: Reliability Test

\begin{tabular}{|l|c|}
\hline Composite Variable & Cronbach's Alpha \\
\hline Entrepreneurship Education Curriculum (EEC) & 0.956 \\
\hline Entrepreneurial Career Choice (ECC) & 0.950 \\
\hline Instrumental Readiness (IR) & 0.806 \\
\hline
\end{tabular}

Each construct above shows Cronbach's alpha readings of $\geq 0.80$. These loadings are acceptable values and well above Hair et al (2007) recommendation of 0.80 at the limit. Hence, it was concluded that all test instruments have achieved the required internal consistency.

\section{Findings}

\section{Demographic Profile of the Respondents}

Through an online survey, 238 usable responses were received. Since all items in the questionnaire were made mandatory before submission, no responses with missing data were detected. Response rate remains a critical concern in research to ensure the validity and reliability of findings (Hair, Black, Babin, Anderson, \& Tatham, 2007). A response rate of 100 percent is only possible if the questionnaire were administered in a coercive manner (Rogelberg \& Stanton, 2007), yet Cook, Heath, and Thompson (2000) argued that representativeness is more important the responsiveness. However, Baruch and Holtom (2008) cautioned that representativeness can only be achieved if there is a sufficient response 
rate. According to Bonometti and Jun (2006), this issue can be mitigated when the web-based survey is occupied. Therefore, this research employed a web-based survey on a voluntary concept. Hence, a response rate of 63.1 percent achieved while most studies at the individual level achieved a response rate of 52.7 percent with recent publications suggesting an average of 50 percent (Baruch \& Holtom, 2008) which is sufficient for statistical analysis. The demographical information of the respondents is provided in Table 2 . Close to equal participation rate was obtained between male and female with female participation at 53.8 percent. As far as ethnicity is concerned, most of the respondents were Malay (i.e. 49.6 percent) followed by Chinese (i.e. 21.0 percent) and Indian (i.e. 18.1 percent). At least half of the respondents who participated in the survey were in the age range of 20 to 30, contributing to about 51.7 percent. Since this survey was conducted among MBA students, the majority of the respondents were working adults where this group constitutes about 80.7 percent of total respondents.

Table 2: Descriptive Statistics

\begin{tabular}{|c|c|c|c|}
\hline & & Frequency & Percentage \\
\hline \multirow[t]{3}{*}{ Gender } & Male & 110 & $46.2 \%$ \\
\hline & Female & 128 & $53.8 \%$ \\
\hline & Total & 238 & $100 \%$ \\
\hline \multirow[t]{5}{*}{ Ethnicity } & Indian & 43 & $18.1 \%$ \\
\hline & Malay & 118 & $49.6 \%$ \\
\hline & Chinese & 50 & $21.0 \%$ \\
\hline & Others & 27 & $11.3 \%$ \\
\hline & Total & 238 & $100 \%$ \\
\hline \multirow[t]{5}{*}{ Age } & $20-30$ & 123 & $51.7 \%$ \\
\hline & $31-40$ & 80 & $33.6 \%$ \\
\hline & $41-50$ & 32 & $13.4 \%$ \\
\hline & $>50$ & 3 & $1.3 \%$ \\
\hline & Total & 238 & $100 \%$ \\
\hline \multirow{5}{*}{$\begin{array}{l}\text { Employment } \\
\text { Status }\end{array}$} & Working Full Time & 192 & $80.7 \%$ \\
\hline & Working Part-Time & 8 & $3.4 \%$ \\
\hline & Self Employed & 9 & $3.8 \%$ \\
\hline & Not Working & 29 & $12.2 \%$ \\
\hline & Total & 238 & $100 \%$ \\
\hline
\end{tabular}

\section{Exploratory Factor Analysis (EFA)}

Hair, Black, Babin, Anderson, \& Tatham (2006) indicated that it is essential to conduct a measure of sampling adequacy involving Bartlett's Test of Sphericity (Bartlett's Test) and Kaiser-Mayer-Olkin (KMO) to justify the application of factor analysis. According to Field (2009), the KMO value range between 0 and 1 with a value closer to 1 considered to be better while Barlett's test examines the existence of significant interrelationships between variables under study. Hence, Bartlett's Test and KMO was performed to ensure that the data set has fulfilled these requirements. Table 3 indicates the result of these tests. 
Table 3: Measure of Sampling Adequacy

\begin{tabular}{|l|l|r|}
\hline \multicolumn{3}{|c|}{ KMO and Bartlett's Test } \\
\hline Kaiser-Meyer-Olkin Measure of Sampling Adequacy. & .914 \\
\hline \multirow{3}{*}{ Bartlett's Test of Sphericity } & Approx. Chi-Square & 2485.057 \\
\cline { 2 - 3 } & df & 120 \\
\cline { 2 - 3 } & Sig. & .000 \\
\hline
\end{tabular}

$\mathrm{KMO}$ value resulted at 0.914 and Bartlett's test significance value is 0.00 which is $<0.05$. Since both statistics are significant and appropriate, factor analysis was conducted considering factor loading guidance offered by Fen and Sabaruddin (2008) and Hair et al., (2006) who indicates that loadings greater than 0.50 reflect a practical significance for it to be retained. Table 4 provides the result of the factor analysis.

Table 4: Variables, Items, and Factor Loadings

\begin{tabular}{|c|c|c|c|}
\hline Variables & Items & & $\begin{array}{l}\text { Factor } \\
\text { Loading }\end{array}$ \\
\hline \multirow[t]{8}{*}{ EEC } & EEC1. & $\begin{array}{l}\text { The courses in MBA curriculum in my institution inspire } \\
\text { me to develop new businesses. }\end{array}$ & 0.721 \\
\hline & EEC2. & $\begin{array}{l}\text { The courses in MBA curriculum foster the social skills } \\
\text { needed by entrepreneurs. }\end{array}$ & 0.801 \\
\hline & EEC3. & $\begin{array}{l}\text { The courses in MBA curriculum foster the leadership skills } \\
\text { needed by entrepreneurs. }\end{array}$ & 0.816 \\
\hline & EEC4. & $\begin{array}{l}\text { The courses in MBA curriculum provide me with the } \\
\text { knowledge necessary to start a business. }\end{array}$ & 0.854 \\
\hline & EEC5. & $\begin{array}{l}\text { The courses in MBA curriculum provides me with the } \\
\text { knowledge necessary to run a business. }\end{array}$ & 0.839 \\
\hline & EEC6. & $\begin{array}{l}\text { The courses in MBA curriculum support building diverse } \\
\text { teams. }\end{array}$ & 0.800 \\
\hline & EEC7. & $\begin{array}{l}\text { The courses in MBA curriculum provide me with a strong } \\
\text { network of entrepreneurial resources (e.g. investors). }\end{array}$ & 0.565 \\
\hline & EEC8. & $\begin{array}{l}\text { The courses in MBA curriculum actively promote the } \\
\text { process of founding a new company. }\end{array}$ & 0.701 \\
\hline \multirow[t]{5}{*}{ ECC } & ECC1. & $\begin{array}{l}\text { Among various career options, l'd rather be an } \\
\text { entrepreneur. }\end{array}$ & 0.830 \\
\hline & ECC2. & A career as entrepreneur is attractive for me. & 0.897 \\
\hline & ECC3. & $\begin{array}{l}\text { If I had the opportunity and resources, I'd like to choose } \\
\text { an entrepreneur as my career. }\end{array}$ & 0.869 \\
\hline & ECC4. & $\begin{array}{l}\text { Entrepreneur as my career would give me great } \\
\text { satisfaction. }\end{array}$ & 0.909 \\
\hline & ECC5. & $\begin{array}{l}\text { An entrepreneur career option implies more advantages } \\
\text { than disadvantages to me. }\end{array}$ & 0.819 \\
\hline \multirow[t]{3}{*}{ IR } & IR1. & I have access to capital to start to be an entrepreneur. & 0.722 \\
\hline & IR2. & $\begin{array}{l}\text { I have good social networks that can be utilized when I } \\
\text { decide to be an entrepreneur. }\end{array}$ & 0.849 \\
\hline & IR3. & $\begin{array}{l}\text { I have access to supporting information to be an } \\
\text { Entrepreneur. }\end{array}$ & 0.792 \\
\hline
\end{tabular}


EFA indicates that all the items are having its factor loadings in the range of 0.565 to 0.909 which are well above 0.50 (Hair et al., 2006). Hence, it was concluded that all constructs under study conform to the convergent validity test.

\section{Convergent Validity}

There are two ways to examine the convergent validity of a construct. They are composite reliability (CR) and also the average variance extracted (AVE). Hair et al. (2010) suggested a CR score of at least 0.70 and AVE threshold of at least 0.50 for a construct to conform to convergent validity. The results of the convergent validity of the study are reported in Table 5. As indicated, all the constructs under study have achieved convergent validity as recommended by Hair et al. (2010) and therefore reflect adequate internal consistency (Bagozzi \& Yi, 1988).

Table 5: Convergent Validity

\begin{tabular}{|c|c|c|c|c|c|}
\hline Construct & Item & Factor Loading & $\begin{array}{c}\text { Cronbach's } \\
\text { Alpha }\end{array}$ & CR & AVE \\
\hline \multirow[t]{6}{*}{ EEC } & EEC1 & 0.566 & \multirow{6}{*}{0.902} & \multirow{6}{*}{0.888} & \multirow{6}{*}{0.573} \\
\hline & EEC2 & 0.769 & & & \\
\hline & EEC3 & 0.820 & & & \\
\hline & EEC4 & 0.807 & & & \\
\hline & EEC5 & 0.816 & & & \\
\hline & EEC6 & 0.732 & & & \\
\hline \multirow[t]{4}{*}{ ECC } & ECC1 & 0.821 & \multirow{4}{*}{0.909} & \multirow{4}{*}{0.895} & \multirow{4}{*}{0.682} \\
\hline & ECC2 & 0.815 & & & \\
\hline & ECC3 & 0.820 & & & \\
\hline & ECC4 & 0.846 & & & \\
\hline \multirow[t]{3}{*}{ IR } & IR1 & 0.824 & \multirow{3}{*}{0.692} & \multirow{3}{*}{0.772} & \multirow{3}{*}{0.533} \\
\hline & IR2 & 0.667 & & & \\
\hline & IR3 & 0.689 & & & \\
\hline
\end{tabular}

\section{Path Coefficient}

The statistical relationship between independent, dependent and mediator variables of the study are displayed in Table 6 and Table 7.

Table 6: Entrepreneurship Education and Entrepreneurial Career Choice

\begin{tabular}{|c|c|c|c|c|}
\hline Independent variable & Standardized Beta & t-value & Sig. ( $p$-value) & $\mathrm{R}^{2}$ \\
\hline Entrepreneurship Education & 0.622 & 12.195 & .000 & 0.387 \\
\hline
\end{tabular}

Based on Table 7, the t-value of this relationship is 12.195 while the $p$-value is $0.000<0.05$. The hypothesis $\mathrm{H} 1$ is significant and a relationship is found between entrepreneurship education and entrepreneurial career choice. The standardized beta value of this relationship is 0.622 which proves that there is a positive association between entrepreneurship education and entrepreneurial career choice. 
Table 7: Path Analysis of Mediating Hypothesis

\begin{tabular}{|l|c|c|c|c|}
\hline Step & Standardized Beta & t-value & Sig. (p-value) & $\mathbf{R}^{\mathbf{2}}$ \\
\hline 1) EE to EEC & 0.622 & 12.195 & .000 & 0.387 \\
\hline 2) EE to IR & 0.503 & 8.948 & .000 & 0.253 \\
\hline 3) IR to EEC & 0.436 & 7.439 & .000 & 0.190 \\
\hline EE and IR predicting & & & & \\
EEC & 0.539 & 9.268 & .000 & 0.407 \\
4) EE & 0.165 & 2.830 & .005 & \\
5) IR & & & & \\
\hline
\end{tabular}

Based on Table 7, all steps 1 to 3 are found to be significant, $p<0.001$ and have allowed mediation testing in Step 4. In step 4, both entrepreneurial education and instrumental readiness variables remain significant, $p<0.001$ which concludes that a partial mediation of instrumental readiness exists on the relationship between entrepreneurship education and entrepreneurial career choice.

\section{Conclusion}

The study examined the relationship between entrepreneurship education and also entrepreneurial career choice among MBA students at UTM. The statistical results provided sufficient evidence that a positive relationship exists between entrepreneurship education and entrepreneurial career choice. An investigation to understand the mediating effect of instrumental readiness on the relationship between entrepreneurship education and entrepreneurial career choice also provided sufficient statistical evidence that there is a mediating effect of instrument readiness on this relationship. The results of this study are in harmony with Yu and Chan (2007) as well as Sharif et al (2011) who claimed that formal education is one of the most important teaching and learning strategies in entrepreneurship education. In order to be receptive to the changing needs of society added with the growing complexities across the world, the curriculum of higher learning institutions needed to be in line with the progress anticipated (Fathi and Shafi'i, 2007). This requires a massive change in the educational curriculum to ensure that it follows the changing trend in the external environment. Such a pressing situation has made entrepreneurship as an important domain in education ( $\mathrm{Yu} \&$ Chan, 2007). This intervention may include several aspects of entrepreneurship education such as business, creativity and innovation, social entrepreneurship, finance and investment, design of the business plan, and business management (Postigo, 2002; Mwasalwiba, 2008). This is when entrepreneurship education transforms into an absolute need for any higher learning institutions in producing selfemployed leaders instead of salary earning employees. From this perspective, it is of the essence to the higher learning institutions to develop students' mental assets such as efforts and the ability to deal with stress and difficulties in order to help students deal with difficult and unexpected changes and the challenges that often occur in business life (Setiawan, 2014). Therefore, orientations toward entrepreneurial curriculum should be an average level (Sharif et al, 2010) while embedded in philosophy and objectives, and theoretical fundamentals, elements of entrepreneurial programs (Imani, 2009). Such intervention into the curriculum creates creativity and risk-taking behavior among the leaners (Owladiyan, 2010). Nevertheless, an entrepreneurial education may require active learning approaches such as exploratory learning, practical and problem-solving, cooperative learning, projects, 
simulations, and role-playing for a better understanding of the domain among the learners (Martin \& Romita, 2014; Mazbouhi, 2011).

\section{Acknowledgments}

The authors would like to thank Universiti Teknologi Malaysia (Vot: 03K20) for providing financial support to publish this paper.

\section{References}

Adejimola, A. S., Olufunmilayo T. O. (2009). spinning off an entrepreneurial culture among Nigerian university students: prospects and challenges. Afr. J. Bus. Manage.3:80-88.

Ahmadpur Dariani, M. (2004). Entrepreneurship experiences in selected countries, Tehran: Publication of Amir Kabir.

Ahmadpur Dariani, M., Azizi, M. (2003). Promoting entrepreneurship through Education College, Economic Journal, 19, 21, 20-24.

Ahmadzadeh, N. (2006). The study of educational science curriculum according to the entrepreneurial skills, Thesis M.A, University of Tehran.

Azahari, J., Abd Razak, M. Y., Hazli, M. R., Hamidon, K., Jimisiah, J., Mohd Fauzi, Z. A., ... Zawiah, A. M. (2013). Technopreneurship. Kuala Lumpur: Oxford Fajar.

Bagozzi, R. P., \& Yi, Y. (1988). On the Evaluation of Structural Equation Models. Journal of the Academy of Marketing Science, 16(1), 74-94.

Baruch, Y., \& Holtom, B. C. (2008). Survey response rate levels and trends in organizational research. Human Relations, Vol. 61(8), pp. 1139-1160.

Beckman, C. M., \& Burton, M. D. (2008). Founding the future: Path dependence in the evolution of top management teams from founding to IPO. Organization Science, Vol. 19(1), pp. 3-24.

Bonometti, R. J. \& Jun, T. (2006). A dynamic technique for conducting online survey-based research. Competitiveness Review, Vol. 16, pp. 97-105.

Burton, M. D., Sorenson, J. B., \& Dobrev, S. D. (2016). A Careers Perspective on Entrepreneurship. Entrepreneurship Theory and Practice, Vol. 40(2), pp. 237-247.

Carnahan, S., Agarwal, R., \& Campbell, B. A. (2012). Heterogeneity in turnover: The effect of relative compensation dispersion of firms on the mobility and entrepreneurship of extreme performers. Strategic Management Journal, Vol. 33(12), pp. 1411-1430.

Chambers, R. (2005). Human capital for entrepreneurship in higher education. London: Edgar.

Clark, A. M. (1998). The qualitative-quantitative debate: Moving from positivism and confrontation to post-positivism and reconciliation. Journal of Advanced Nursing, Vol. 27(6), pp. 1242-1249.

Cook, C., Heath, F., \& Thompson, R. L. (2000). A meta-analysis of response rates in web- or internet-based surveys. Educational and Psychological Measurement, Vol. 60, pp. 82136.

Dopson, L. R., and Tas, R. F. (2004). A practical approach to curriculum development: a case Study. Journal of Hospitality and Tourism Education, 16(1), 39-46.

Douglas, E. J., \& Shepherd, D. A. (2002). Self-employment as a Career Choice: Attitudes, Entrepreneurial Intentions, and Utility Maximization. Entrepreneurial Theory and Practice, 26(3), 81-90.

Dutta, D., \& Crossan, M. (2005). The nature of entrepreneurial opportunities understanding the process using the oranizational learning framework; Baylor University, Entrepreneurship: theory and practice. 
Dyer, W. G. J. (1994). Towards a theory of entrepreneurial careers. Entrepreneurship Theory and Practice, 19(2), 7-21.

Fakour, B. (2008). Entrepreneur University, Journal of Technology Grow, 5, 35-42.

Fanning, E. (2005). Formatting a paper-based survey questionnaire: best practices. Practical Assessment Research \& Evaluation, Vol. 10(12), pp. 1-14.

Fathi, K., Shafi'i, N. (2007). Assess the quality of the academic curriculum, Journal of Curriculum Studies, 2, 5, 1-26.

Fen, Y. S., and Sabaruddin, N. A. (2008). An Extended Model of Theory of Planned Behaviour in Predicting Exercise Intention. International Business Review, 1(4), 108-122.

Field, A. (2009). Discovering Statistics Using SPSS: Introducing Statistical Method (3rd ed.). Thousand Oaks, CA: Sage Publications.

Gibb, A. (2002). Entrepreneurship and small business management: can we afford to neglect them in the twenty first century business school? British Academy of Management Review, 4;

Guest, G., Namey, E. E., \& Mitchell, M. L. (2013). Collecting Qualitative Data: A Field Manual for Applied Research. Los Angeles: Sage.

Gursoy, D., and Swanger, N. (2004). An industry-driven model of hospitality curriculum for programs housed in accredited colleges of business. Journal of Hospitality and Tourism Education, 16(4), 13-20.

Gursoy, D., and Swanger, N. (2005). An industry-driven model of hospitality curriculum for programs housed in accredited colleges of business - Part II. Journal of Hospitality and Tourism Education, 17(2), 46-56.

Hair, J. F., Black, W., Babin, B., Anderson, R., \& Tatham, R. L. (2007). Multivariate data analysis, 6th edn. Englewood Cliffs, NJ: Prentice Hall.

Henderson, R., \& Robertson, M. (2000). Who wants to be an entrepreneur? Young adult attitudes to entrepreneurship as a career. Career Development International, 5(6), 279287.

Huggins, R. (2000). The success and failure of policy-implanted inter-firm network initiatives: motivations, processes and structure. Entrepreneurship and Regional Development, 12(2), 11-135.

Imani, M. N. (2009). Entrepreneurship education in Universities, Journal of Research in Educational Management, 27, 1-50.

Moghadam, J. S. (2012). Review the content of the curriculum of Library to develop an entrepreneurial attitude, Journal of Curriculum Studies in Higher Education, 3, 5, 49-68.

Johnson, B., \& Christensen, L. (2012). Educational Research: Quantitative, Qualitative, and Mixed Approaches (4th edition). Thousand Oaks, CA: Sage.

Joona, P. A., \& Wadensjo, E. (2013). The best and the brightest or the least successful? Selfemployment entry among mail wage-earners in Sweden. Small Business Economics, Vol. 40, pp. $155-172$.

Khalid, K., Hilman, H., \& Kumar, K. M. (2012). Get along with quantitative research process. International Journal of Research in Management, Vol. 2(2), pp. 15-29.

Kolvereid, L., and Moen, O. (1997). Entrepreneurship among business graduates: does a major in entrepreneurship make a difference? Journal of European Industrial Training, 21(4), 154-60.

Kristiansen, S., \& Indarti, N. (2004). Entrepreneurial intention amongIndonesian and Norwegian students. Journal of Entreprising Culture, 12 (1), 55-78. 
Kristiansen, S., Furuholt, B., \& Wahid, F. (2003). Internet cafe entrepreneurs: pioneers in information dissemination in Indonesia. The International Journal of Entrepreneurship and Innovation, 4(4), 251-263.

Krueger, N. (1993). The impact of prior entrepreneurial exposure on perceptions of new venture feasibility and desirability. Entrepreneurship Theory and Practice, 18(1), 5-21.

Lofstrom, M., Bates, T., \& Parker, S. C. (2014). Why are some people more likely to become small businesses owners than others: Entrepreneurship entry and industry-specific barriers. Journal of Business Venturing, Vol. 29(2), pp. 232-251.

Lunenburg, F. C., \& Ornstein, A. C. (2004). Educational administration, concepts and practices "Wadsworth Publishing Complaining.

Maleki, H. (2008). Curriculum, Mashhad: Thought Message.

Martin, C., \& Romita, B. I. (2014). Teaching entrepreneurship to educational sciences students, 5th World Conference on Educational Sciences - WCES 2013, 4397 - 4400.

Mat, S. C., Maat, S. M., \& Mohd, N. (2015). Identifying factors that affecting the entrepreneurial intention among engineering technology students. Procedia-Social and Behavioral Sciences, 211, 1016-1022.

Matlay, H. (2008). Entrepreneurship education in China, Journal of Education and Training, 45, 8-9. 445- 505.

Mazbouhi, S. (2011). Entrepreneurship education curriculum, Creativity and Innovation in Human Sciences, 1, 3, 13-30.

Mwasalwiba, E. S. (2008). Entrepreneurship education: a review of its objectives, teaching methods, and impact indicators. Journal of Education and Training, 25, 1, 20-47.

Norouzzadeh, R., \& Kowsari, M. (2009). Defining features of the curriculum of undergraduate with emphasis on developing entrepreneurial skills, Research \& Planning in Higher Education, 1, 15-18.

Owladiyan, M. (2010). Compare the attitude of graduate's entrepreneurship based on individual characteristics and job \& academic variables about factors affecting the development of entrepreneurship in the curriculum of education, Iran Social Development, 3, 2, 113-123.

Plattner, I. E. (2009). Are university students psychologically ready for Entrepreneurship? A Botswana study" African Journal of Business Management, 3 (7), 305-310.

Postigo, S. (2002). Entrepreneurship education in Argentina. The case of Sanders University. Paper presented for the Internalizing Entrepreneurship Education Conference in Malaysia, July 8-10.

Rogelberg, S., \& Stanton, J. (2007). Understanding and dealing with organizational survey nonresponse. Organizational Research Methods, Vol. 10, pp. 195-209.

Saunders, M., Lewis, P., \& Thornhill, A. (2006). Research methods for business students, 4th edn. Harlow: Prentice Hall.

Saunders, M., Lewis, P., \& Thornhill, A. (2012). Research Methods for Business Students" 6th edition. Pearson Education Limited.

Scott, M., \& Twomey, D. (1988). The long-term supply of entrepreneurs: Students' career aspirations in relation to entrepreneurship. Journal of Small Business Management, 26(4), 5-13.

Segal, G., Borgia, D., \& Schoenfeld, J. (2005). The motivation to become an entrepreneur. International Journal of Entrepreneurial Behaviour \& Research, 11(1), 42-57. 
Setiawan, J. L. (2014). Examining entrepreneurial self-efficacy among students, The 5th Indonesia International Conference on Innovation, Entrepreneurship, and Small Business (IICIES 2013), $235-242$.

Setiawan, J. L. (2012). Entrepreneurship Program Assessment by Students Outcome on Their Perceived Entrepreneurial Characteristics. Paper presented at Indonesia International Conference on Innovation. Entrepreneurship. and Small Business, Surabaya. 26-28 June 2012.

Sharif, M., Jamshidian, A., Rahimi, H., \& Naderi, N. (2011). The analysis of Entrepreneurship education in Higher Education, 87, 106-111.

Singh, K. A., \& Krishna, K. V. S. M. (1994). Agricultural Entrepreneurship: The Concept and Evidence. Journal of Entrepreneurship, 3(1), 97-111.

Snider, J. (2010). Commentary. The cult of statistical pyrotechnics. Education Week, Vol. 29(21), pp. 20-21.

Steel, W. F. (1994). Changing the Institutional and Policy Environment for Small Enterprise Development in Africa. Small Enterprise Development, 5(2), 4-9.

Turker, D., \& Selcuk, S.S. (2009). Which factors affect entrepreneurial intention of university students? Journal of European Industrial Training. 33(2),142 - 159.

Yadollahi, J. (2009). Studying entrepreneurship education curriculum in the field of educational sciences, Journal of entrepreneurship Development, 1, 3, 61-86.

Yu, M. C., \& Chan, S. (2007). Entrepreneurship education in Malaysia (www.MMu.edu).

Zabihi, M., Moghadasi, A. (2006). Entrepreneurship: theory to action, Mashhad, Tomorrow. 